\title{
Graft Dosage Form
}

National Cancer Institute

\section{Source}

National Cancer Institute. Graft Dosage Form. NCI Thesaurus. Code C45416.

A solid composed of a piece of skin or other tissue intended for implantation into or on the body. 